\title{
Biotic and Abiotic Factors Affecting Productive Performance of Rotifers (Brachionus Plicatilis) Population Produced Under 3 Days Batch Culture System
}

\author{
Omar, E.A., ${ }^{1}$ Essa, M.A., ${ }^{2}$ Srour, T.M., ${ }^{1}$ and Mater, M.M. ${ }^{2}$ \\ ${ }^{1}$ Dept.Animal and Fish Production, Faculty of Agriculture (Saba Basha), Alexandria \\ University, Alexandria, Egypt. ${ }^{2}$ Fish Rearing Lab, Aquaculture Division, National \\ Institute of Oceanography and Fisheries, Alexandria, Egypt.
}

Corresponding author: Mater, M.M, e-mail : mhsy 4@yahoo.com

\begin{abstract}
Rotifers Brachionus plicatilis are being used worldwide to feed early developmental stages of marine finfish and crustaceans. Further, rotifer transmits adequate supplies of micro and macro-nutrients, vitamins, probiotic, and even antibodies to fish larvae. Food type is regarded as the most important criterion that could affect growth and quality of rotifers. There fore, the present work was performed to study the effect of food type, salinity, water temperature, and initial stocking density on the population growth of rotifers. The first experiment was conducted to during the first phase of the present study investigate the effect of four different algal diets: (1) Nannochloropsis oculata life (N), (2) Spirulina platensis powder (S), (3) $50 \% \mathrm{~N}$. oculata $+50 \%$ beaker yeast (NY), and (4) $50 \%$ S. platensis $+50 \%$ beaker yeast, on rotifer population (as final number/ml) and fatty acid profile of rotifer batch cultured $(72 \mathrm{~h}$ ) was employed. Rotifer culture treatments were conducted in jars (30 liters) with three replicates for each treatment.The results of the firts phase of the study clearly illustrated that NY diet possessed the highest population growth, Eicosapentaenoic acid (EPA), and Docosahexaenoic acid DHA percentage. Depending on the results of the first phase, the diet NY was candidate to investigate the effect of different salinities $(25,27$, and $29 \mathrm{ppt})$, temperatures $\left(26,28,30,32{ }^{\circ} \mathrm{C}\right)$, and initial rotifer stocking densities $(50,100,150$, and $200 \mathrm{Ind} . / \mathrm{ml})$ on rotifer population. The results showed that salinity $25 \mathrm{ppt}$, temperature $28^{\circ} \mathrm{C}$, and initial rotifer density $150 \mathrm{pcs} / \mathrm{ml}$ possessed the highest rotifer population growth during a 72-hrs batch culture system of rotifer when fed on $50 \%$ N. oculata $+50 \%$ beaker yeast (NY) food type.
\end{abstract}

Keywords: Rotifers, Brachionus plicatilis, food type, salinity, temperature, stocking density

\section{INTRODUCTION}

Rotifer (Brachionus plicatilis) is a cyclically parthenogenetic organism that appears regularly and typically in saltwater lakes and coastal lagoons. Several studies revealed that $B$. plicatilis was a complex species and at least three sympatric species (Brachionus plicatilis, Brachionus rotundiformis and Brachionus ibericus) have been observed. The two species $B$. plicatilis and $B$. rotundiformis are used worldwide, alone or in conjunction with other types of food to feed early developmental stages of marine finfish and crustaceans under hatchery conditions. Further, rotifer transmits adequate supplies of micro and macro-nutrients, vitamins and even antibodies to fish larvae (Lubzens et al., 2001). However, among them $B$. plicatilis was widely used as live feed in aquaculture. Moreover, $B$. plicatilis are currently essential for intensive culture of marine larval fish in many hatcheries throughout the world (Fielder, et al., 2000). Rotifer size varies in response to different environmental conditions. The fish larvae select the rotifers according to their size, and this resulted in increasing growth rate, and reduces mortality (Qie et al., 2011).

Diet is regarded as the most important criterion that could affect growth and quality of rotifers. Moreover, $B$. plicatilis cultures are often influenced by variety of food types as diets. Rotifers density, production, fecundity, and growth 
rate were dependent on food availability and quality (Ferreira et al., 2011). Microalgae are the first found to be an excellent food that could provide best rotifer quality and quantity for marine fish larvae (Yin and Zhao, 2008). The microalga Chlorella, Nannochloropsis, and Tetraselmis have often been used as exclusive food in culturing $B$. plicatilis (Lubzens et al., 1997). However, Ashour (2011) reported that Nannochloropsis may be the best microalgal species used as rotifer feed. Rotifer quality is often enhanced by different enrichment techniques. For example, it has been suggested that the replacement of baker's yeast supplemented with oils rich in n-3 HUFA can be used as an alternative food for rotifer culture. However, using yeast could deteriorate water quality (Nhu, 2004).

A large number of researches have been reported that temperature, salinity and food types have variable effects on productivity of different strains of rotifers (Miracle and Serra, 1989, Fulks and Main, 1991). On the other hand, the density of rotifers in the water column has a significant effect on the feeding success of marine fish larvae by influencing the probability of encounter (Fielder et al., 2000).

The aims of the present study were to:

1- Investigate the effect of different algal diets (Nannochloropsis oculata or Spirulina platensis) as a single diet or a supplemented diet with baker's yeast (Saccaromysis cervicates) on rotifer population, as increase in number.

2- Investigate the effect of different water salinities, temperatures, and initial rotifer culture densities on rotifer population growth during a batch culture of rotifer (72 hrs.).

\section{MATERIAL AND METHODS MATERIALS}

The experiments were conducted in Fish Rearing Laboratory, El-Max Research Station, Aquaculture Division, National Institute of oceanography and Fisheries (NIOF) Alexandria, Egypt. The culture water used in these experiments were obtained from a saline ground water $(30 \pm 2 \mathrm{ppt})$. The rotifers $B$. plicatilis ( $\mathrm{L}$ - type with average length $\sim 200 \mu \mathrm{m}$ ) were obtained from a routine culture at the marine Finfish hatchery of NIOF. The present study was divided into two phases using patch culture system, each one was continued for 72 hrs. The necessary dilution to the desired initial density of rotifer was accomplished using sterilized and filtered seawater. The algal cell density was determined with a haemocytometer and the rotifer density with a 1- ml glass pipette using Sedgwick-Rotifer chamber. Rotifer culture treatments were conducted in special jars (30 liters) with three replicates for each treatment .

\section{Phase1: study the effect of different food type on rotifer productive performance and its fatty acids content:}

Four treatments were conducted, from different algal species and yeast, as food for rotifer; (1) Nannochloropsis oculata $(\mathbf{N})$ at $15 \times 10^{4}$ cell/ind/day (Wendy and Kevan 1991), (2) Nannochloropsis oculata + dried yeast (NY) at $0.5 \mathrm{~g} / 10^{6}$ ind., (3) dried Spirulina (Spirulina platensis) (S) at $0.5 \mathrm{~g} / 10^{6}$ ind. and (4) dried Spirulina $\left(0.5 \mathrm{~g} / 10^{6}\right.$ ind )+dried yeast (SY) $\left(0.5 \mathrm{~g} / 10^{6} \mathrm{ind}\right)$. The culture conditions during the experiment were: salinity $25 \mathrm{ppt}$, temperature $30^{\circ} \mathrm{C}, \mathrm{pH}$ 
7.8 and desolved oxegen(DO) was $4 \mathrm{mg} / \mathrm{l}$. The initial rotifer density was conducted at 100 ind. /ml (fulks and main, 1991).

\section{Phase 2: Effect of salinity, temperature and initial density on rotifer productive performance:}

Depending on the results of the phase 1, the treatment NY which possessed the highest rotifer final number (population), as well as achieved the highest polyunsaturated fatty acid, Eicosapentaenoic acid (EPA) and Docosahexaenoic acid (DHA) percent. Accordingly, this treatment was selected and candidate to investigate the effects of different salinity, temperature and initial density on rotifer productive performance.

Salinity experiment was conducted at three levels; 25, 27, and 29 ppt. Each level was tested under controlled conditions of temperature $26 \pm 1^{\circ} \mathrm{C}$, DO $4 \mathrm{mg} / \mathrm{l}$, and $\mathrm{pH}$ 7.8. The initial rotifer density was conducted at $100 \mathrm{ind}$. $/ \mathrm{ml}$.

Temperature experiment was conducted at four levels; 26, 28, 30, 32 ${ }^{\circ} \mathrm{C}$. Each level was tested under controlled conditions of salinity $25 \mathrm{ppt}$, DO 4 $\mathrm{mg} / \mathrm{l}$, and $\mathrm{PH}$ 7.8. The initial rotifer density was conducted at $100 \mathrm{ind} . / \mathrm{ml}$.

The previously recorded optimum water quality parameters of Salinity $25 \%$, temperature $28{ }^{\circ} \mathrm{C}$ and the best food type of NY were subsequently provided to test the best initial rotifer cultured densities from between 50, 100, 150 and 200 ind. $/ \mathrm{ml}$.

\section{Experimental methodology:}

Productive performance of rotifer: At the end of the experiments, as well as at the end of every day during experiments, $1 \mathrm{ml}$ of rotifer culture from each treatment was collected five times and counted to determine the average final number of rotifer, as a population of rotifers B. plicatilis (Ashour, 2011).

Fatty acids analysis: Preparation of fatty acids methyl ester from total lipids was performed according to the procedure of Radwan (1978). All analysis for identification of fatty acids fractions were performed on gas chromatography instrument, model HP (Hewlett Packard) 7890 GC equipped with a flame ionization detector. The conditions for fatty acid analysis were:

\begin{tabular}{l|l}
\hline Column & $\begin{array}{l}\mathrm{HP}-5,30 \mathrm{~m}, 0.32 \mathrm{~mm} \mathrm{ID}, 0.25 \mu \mathrm{m} \text { film } \\
\text { thickness }\end{array}$ \\
\hline Detector & $\mathrm{FID}$ \\
Detector temperature & $250^{\circ} \mathrm{C}$ \\
Injected temperature & $220^{\circ} \mathrm{C}$, injection volume $2 \mu \mathrm{l}$, splitless mode \\
Carrier Gas & Nitrogen \\
Gas Flow & $1 \mathrm{ml} / \mathrm{min}$. \\
\hline
\end{tabular}

Water quality: During this experiment, temperature was kept at $30 \pm 0.5^{\circ} \mathrm{C}$, salinity $25 \mathrm{ppt}$, and $\mathrm{pH} 7.45-7.8$. Dissolved oxygen concentrations was $4 \mathrm{mg} / \mathrm{l}$ at the starting time and decreased after three days of culturing to 2.3, 2.4, 2.6, and $2.4 \mathrm{mg} / \mathrm{l}$ for treatments, S, SY, N, and NY, respectively. Total ammonia concentrations at the starting time varied between $0.54-0.55 \mathrm{mg} / \mathrm{l}$ and 
increased after three days of culturing to $0.78,0.76,0.78$, and $0.77 \mathrm{mg} / \mathrm{l}$ for treatments, S, SY, N, and NY, respectively.

\section{Statistical Analyses:}

At the termination of the experiments, Total Number of Rotifer (millions) in days 1, 2, and 3 , Final Density (ind/ml), Total Increment of rotifer (Millions in 3 days/30 litres), Average Daily Increment (Millions/30 litres/ day), and Average Increment per day (\%) were subjected to One-way analysis of variance (ANOVA) using the software Package (SPSS Version 16) to test the significance between treatments (water temperature, water salinity, feeding types, and rotifer density). The differences between Rotifer culture system treatments were performed using LSD test with 0.05 significance level according to Steel and Torrie (1980).

\section{Growth performance, and feed utilization parameters}

Means of weight gain, percentage weight gain, average daily gain (ADG) and specific growth rate (SGR \% / day) were calculated according to the following equations:

Weight gain = W1 - W0.

Percentage weight gain (WG \%) $=\{(\mathrm{W} 1-\mathrm{W} 0) / \mathrm{W} 0\} \times 100$.

Average daily gain $(A D G)=$ weight gain/experimental period $(d)$.

Specific growth rate $($ SGR \%) $=\{(\ln W 1-\ln W 0) / T)\} \times 100$.

Where:

W0: Mean initial weight $(\mathrm{g})$.

W1: Mean final weight $(\mathrm{g})$.

$\mathrm{T}$ : Time in days between weightings.

Means of feed conversion ratio (FCR), protein efficiency ratio (PER) and Protein Productive Value (PPV \%) were calculated according to the following equations:

Feed conversion ratio (FCR) = Feed intake (g) / Weight gain (g).

Protein efficiency ratio $(P E R)=$ Weight gain $(\mathrm{g})$. / Protein intake $(\mathrm{g})$.

Protein Productive Value (PPV \%) $=\{(\mathrm{BP} 1-\mathrm{BP} 0) / \mathrm{CP}\} \times 100$.

Where:

BP0: Initial body protein content $(\mathrm{g})$

BP1: Final body protein content $(\mathrm{g})$

CP: Protein intake $(g)$

Condition Factor:

$\mathrm{k}=\mathrm{FW} / \mathrm{L} 3 \mathrm{X} 100$

Fulton's condition factor $\mathrm{K}$ with $\mathrm{W}$ whole body wet weight In grams and $\mathrm{L}$ length in $\mathrm{cm}$; the factor 100 is used to bring $\mathrm{K}$ close to unity.

\section{RESULTS:}

\section{Food type:}

The results of the effect of different food types (N, NY, S, and SY) on rotifers ( $B$. Plicatilis) population showed that there were significant differences between all treatments ( $\mathrm{P} \leq 0.05)$, as showed in Table 1.

In the first day, data showed that NY diet achieved the highest significant total number of rotifer $\left(2.25 \pm 0.042 \times 10^{6} / 30 \mathrm{~L}\right)$, followed by SY $\left(2.18 \pm 0.157 \times 10^{6} / 30 \mathrm{~L}\right)$, and $N\left(1.86 \pm 0.170 \times 10^{6} / 30 \mathrm{~L}\right)$, while the lowest $\left(1.80 \pm 0.085 \times 10^{6} / 30 \mathrm{~L}\right)$ was achieved by $S$ diet. In the second day, our results showed that NY achieved the highest significant total number of rotifer 
$\left(3.06 \pm 0.085 \times 10^{6} / 30 \mathrm{~L}\right)$, followed by SY $\left(2.88 \pm 0.212 \times 10^{6} / 30 \mathrm{~L}\right)$, and $\mathrm{S}$ $\left(2.52 \pm 0.099 \times 10^{6} / 30 \mathrm{~L}\right)$, while the lowest value was recorded by $\mathrm{N}$ diet $\left(2.52 \pm 0.099 \times 10^{6} / 30 \mathrm{~L}\right)$. while, the results obtained at the third day observed that the highest significant total number of rotifer was achieved by NY $\left(4.74 \pm 0.169 \times 10^{6} / 30 \mathrm{~L}\right)$ followed by $\mathrm{SY}\left(4.50 \pm 0.127 \times 10^{6} / 30 \mathrm{~L}\right)$, and $\mathrm{N}\left(3.60 \pm 0.255 \times 10^{6} / 30 \mathrm{~L}\right)$, but the lowest was achieved by $S$ diet $\left(3.12 \pm 0.084 \times 10^{6} / 30 \mathrm{~L}\right)$, as shown in table (1). On the other hand, the highest significant final density ( $\mathrm{Ind} . / \mathrm{ml}$ ) of $B$. plicatilis was achieved by NY diet $(158 \pm 5.656$, Ind./ml), followed by SY $(150 \pm 4.243$ Ind./ml), and $\mathrm{N}$ $(120 \pm 8.485 \mathrm{Ind} . / \mathrm{ml})$, while the lowest was achieved by $S(104+2.828$ Ind./ml).Similar trend was observed in the daily increment percentage,, the highest significant daily increment percentage (\%) was achieved by NY $(72 \%)$, SY $(66.7 \%)$, and N (46.7\%), while the lowest was achieved by S diet (36\%).

Table 1: Effect of different food types on the productive performances of rotifers B. plicatilis

\begin{tabular}{|c|c|c|c|c|c|c|c|c|}
\hline \multirow{2}{*}{$\begin{array}{c}\text { Food Types } \\
\text { (Treatments)* }\end{array}$} & \multicolumn{4}{|c|}{ Total Number of Rotifer $\left(\times 10^{6} / 30 \mathrm{~L}\right)$} & \multirow{2}{*}{$\begin{array}{l}\text { Final Density } \\
(\text { Ind./ml)*** }\end{array}$} & \multirow{2}{*}{$\begin{array}{c}\text { Total Increment } \\
\left(\times 10^{6} / 3\right. \\
\text { days } / 30 \mathrm{~L})\end{array}$} & \multirow{2}{*}{$\begin{array}{c}\text { Average Daily } \\
\text { Increment }\left(\times 10^{6}\right. \\
/ 3 \text { days } / 30 \mathrm{~L})\end{array}$} & \multirow{2}{*}{$\begin{array}{l}\text { Average daily } \\
\text { Increment (\%) }\end{array}$} \\
\hline & Day 0** & Day 1 & Day 2 & Day 3 & & & & \\
\hline$S$ & 1.5 & $1.80 \pm 0.09^{b}$ & $2.52 \pm 0.10^{b}$ & $3.12+0.09^{c}$ & $104 \pm 2.83^{c}$ & $1.62 \pm 0.09^{c}$ & $0.54 \pm 0.03^{c}$ & $36.0 \pm 1.88^{c}$ \\
\hline SY & 1.5 & $2.18 \pm 0.16^{\mathrm{a}}$ & $2.88 \pm 0.21^{a}$ & $4.50+0.13^{a}$ & $150+4.24^{a}$ & $3.00 \pm 0.13^{a}$ & $1.00+0.04^{a}$ & $66.7+2.83^{a}$ \\
\hline $\mathrm{N}$ & 1.5 & $1.86 \pm 0.17^{b}$ & $2.43 \pm .08^{b}$ & $3.60 \pm 0.26^{b}$ & $120 \pm 8.49^{b}$ & $2.10 \pm 0.26^{b}$ & $0.70 \pm 0.09^{b}$ & $46.7 \pm 5.66^{b}$ \\
\hline NY & 1.5 & $2.25 \pm 0.04^{a}$ & $3.06 \pm .08^{\mathrm{a}}$ & $4.74 \pm 0.17^{a}$ & $158 \pm 5.66^{a}$ & $3.24 \pm 0.17^{a}$ & $1.08 \pm 0.06^{a}$ & $72.0 \pm 3.78^{a}$ \\
\hline Average & 1.5 & $2.02 \pm 0.23^{*}$ & $2.72+0.29 *$ & $3.99+0.72 * *$ & $133 \pm 23.84^{* *}$ & $2.49 \pm 0.72^{* *}$ & $0.82 \pm 0.24 * *$ & $55.34+15.89^{* *}$ \\
\hline
\end{tabular}

The results of fatty acids profile of $B$. plicatilis feed on N, NY, S, and SY were shown in Table 2. Rotifer fed on $S$ diet achieved the highest total saturated fatty acids (TSFA) percentage $(52.30 \%)$, followed by SY $(38.66 \%)$ and N (37.93\%), while the lowest TSFA was achieved by NY (24.18\%). Palmitic acid $\mathrm{C} 16: 0$ was the main fatty acid (FA) presented in all treatments; it was achieved $(28.13,21.85,26.80$, and $10.91 \%)$ at S, SY, N, and NY diet, respectively. The second main FA obtained in SFA was C18:0, it was 5.02, $10.05,6.04$, and $10.91 \%$ at S, SY, N, and NYdiet, respectively. Furthermore, rotifer fed on $S$ achieved the highest total monounsaturated fatty acids (TMUFA) percentage $(20.78 \%)$, followed by NY $(6.18 \%)$ and $N(5.12 \%)$, while the lowest TMUFA was achieved by SY diet (4.57\%). Moreover, rotifer fed on S diet achieved the lowest total polyunsaturated fatty acids (TPUSFA) percentage $(6.23 \%)$, followed by SY (7.93\%) and N (11.79\%), while the highest TPUSFA was achieved by NY (13.65\%). As well as, rotifer fed on NY achieved the highest DHA percentage $(10.99 \%)$ and EPA $(2.66 \%)$, comparing to rotifer fed on $\mathrm{N}(8.60$ and $2.08 \%)$ and $S(0.64$ and $1.85 \%)$, respectively. Further, rotifer fed on SY did not possessed any DHA percent, while possessed EPA about 1.83\% of total fatty acids.On the other hand, rotifer fed on NY recorded the highest omega3( $\Sigma U-3)(13.66 \%)$, comparing to $\mathrm{N}(10.99 \%), \mathrm{S}(2.49 \%)$ and SY $(1.83 \%)$, while did not achieved any omega6 ( $(\Sigma U-6)$ percentage, comparing to SY $(6.10 \%)$, S $(3.74 \%)$, and $\mathrm{N}(0.80 \%)$. 
EPA/DHA ratio was high (2.89) in rotifer fed on $S$ diet, comparing to rotifer fed on $N(0.24)$ and NY (2.24), while DHA/EPA was low (0.35)in rotifer fed on $S$ diet, comparing to rotifer fed on $N(4.14)$ and NY (4.12), as shown in Table 2.

Table 2: Fatty acid profiles (\% of total FA) of different food types used as rotifer feed.

\begin{tabular}{|c|c|c|c|c|}
\hline \multirow{2}{*}{ Fatty acid profiles } & \multicolumn{4}{|c|}{ Feeding Types } \\
\hline & $\mathbf{S}$ & SY & ND & NY \\
\hline \multicolumn{5}{|l|}{ Saturated } \\
\hline C8:0 & 6.77 & 1.03 & 0.21 & ND** \\
\hline C10:0 & 2.56 & 0.90 & 0.30 & ND \\
\hline C11:0 & 2.21 & 0.90 & 0.38 & ND \\
\hline $\mathrm{C} 12: 0$ & 0.40 & 0.17 & 0.49 & ND \\
\hline C13:0 & 1.25 & ND & 0.12 & ND \\
\hline $\mathrm{C} 14: 0$ & 0.34 & 1.18 & 1.90 & 1.57 \\
\hline $\mathrm{C} 15: 0$ & 0.20 & 1.34 & 1.13 & 0.78 \\
\hline $\mathrm{C} 16: 0$ & 28.13 & 21.85 & 26.80 & 10.91 \\
\hline $\mathrm{C} 17: 0$ & 0.21 & 1.184 & ND & ND \\
\hline C18:0 & 5.02 & 10.05 & 6.04 & 10.91 \\
\hline $\mathrm{C} 20: 0$ & 0.28 & $\mathrm{ND}$ & ND & ND \\
\hline $\mathrm{C} 21: 0$ & 4.90 & ND & 0.51 & ND \\
\hline SUM & $\mathbf{5 2 . 3 0}$ & 38.66 & 37.93 & 24.18 \\
\hline \multicolumn{5}{|l|}{ Monounsaturated } \\
\hline C14:1 & 0.34 & 0.38 & 0.12 & 0.456 \\
\hline $\mathrm{C} 15: 1$ & 0.33 & ND & 0.32 & $\mathrm{ND}$ \\
\hline C16:1 & 0.58 & 1.74 & 0.42 & 0.90 \\
\hline $\mathrm{C} 17: 1$ & 0.10 & ND & 0.62 & 0.88 \\
\hline $\mathrm{C} 18: 1 \mathrm{c}$ & 17.44 & ND & ND & ND \\
\hline $\mathrm{C} 20: 1$ & 1.68 & ND & 0.24 & ND \\
\hline $\mathrm{C} 22: 1$ & 0.29 & 2.44 & 3.38 & 3.94 \\
\hline SUM & 20.78 & 4.57 & 5.12 & 6.18 \\
\hline \multicolumn{5}{|l|}{ Polyunsaturated } \\
\hline$C 18: 2 n-6$ & ND & 0.74 & 0.60 & ND \\
\hline $\mathrm{C} 18: 3 n-3$ & ND & ND & 0.30 & ND \\
\hline $20: 2 n-6$ & 1.86 & 2.68 & ND & ND \\
\hline C20:4n-6 & ND & ND & ND & ND \\
\hline$C 20: 5 n-3$ & 1.85 & 1.83 & 2.08 & 2.66 \\
\hline$C 22: 2 n-6$ & 1.86 & 2.68 & 0.2 & ND \\
\hline $\mathrm{C} 22: 6 n-3$ & 0.64 & ND & 8.60 & 10.99 \\
\hline SUM & 6.23 & 7.93 & 11.79 & 13.65 \\
\hline Total conc. of FA in mg/g of dw & 79.32 & 51.17 & 54.85 & 44.03 \\
\hline Sat./Unsat. & 1.94 & 3.09 & 2.24 & 1.22 \\
\hline$\Sigma U-3$ & 2.49 & 1.83 & 10.99 & 13.66 \\
\hline$\Sigma U-6$ & 3.74 & 6.10 & 0.80 & 0.00 \\
\hline EPA/DHA & 2.89 & - & 0.24 & 0.24 \\
\hline DHA/EPA & 0.35 & - & 4.14 & 4.12 \\
\hline
\end{tabular}

ND: non detected 


\section{Management parameters during the second experimental phase:}

\section{Effect of Salinity ;}

The results of the effect of different water salinities $(25,27$, and $29 \mathrm{ppt})$ on rotifers ( $B$. Plicatilis) population showed that there were significant differences between all treatments $(P \leq 0.05)$, as showed in Table 3 . In the first day, data showed that salinity $25 \mathrm{ppt}$ recorded the highest significant total number of rotifer $\left(2.365 \pm 0.495 \times 10^{6} / 30 \mathrm{~L}\right)$, followed by $27 \mathrm{ppt}\left(2.100 \pm 0.042 \times 10^{6} / 30 \mathrm{~L}\right)$, while the lowest significant total number of rotifer $\left(2.000 \pm 0.014 \times 10^{6} / 30 \mathrm{~L} \mathrm{~L}\right)$ was recorded by $29 \mathrm{ppt}$. In the second day, our results showed that salinity 25 and $27 \mathrm{ppt}$ achieved the highest significant total number of rotifer $\left(3.285 \pm 0.021 \times 10^{6} / 30 \mathrm{~L}\right)$ and $\left(3.240 \pm 0.042 \times 10^{6} / 30 \mathrm{~L}\right.$ respectively). The lowest significant total number of rotifer, $2.130 \pm 0.042 \times 106 / 30 \mathrm{~L}$ was achieved by 29 ppt. As well as, the results obtained from the third day showed similar trends, salinity 25 and 27 ppt possessed the highest significant total number of rotifer $\left(3.285 \pm 0.021 \mathrm{X} 10^{6} / 30 \mathrm{~L}\right)$ and $\left(3.240 \pm 0.042 \times 10^{6} / 30 \mathrm{~L}\right.$ respectively), while the lowest significant total number of rotifer $\left(2.130 \pm 0.042 \times 10^{6} / 30 \mathrm{~L}\right)$ was achieved by 29 ppt, as shown in Figure 2. On the other hand, the highest significant final density of $B$. plicatilis was achieved by salinity $25 \mathrm{ppt}(1.865 \pm 0.007 \mathrm{Ind} . / \mathrm{ml})$ and $27 \mathrm{ppt}(1.795 \pm 0.007 \mathrm{Ind} . / \mathrm{ml})$, respectively, while the lowest was achieved by 29 ppt $(1.320 \pm 0.042 \mathrm{Ind} . / \mathrm{ml})$. Furthermore, the highest daily Increment percentage (\%) was achieved by salinity 25 ppt $(41.33 \%)$ and 27 ppt (40.00\%), respectively, whereas the salinity $29 \mathrm{ppt}$ achieved the lowest daily Increment $(29.34 \%)$. 
Table3: Effect of different salinities on the productive performance of rotifers $B$. plicatilis

\begin{tabular}{|c|c|c|c|c|c|c|c|c|}
\hline \multirow{2}{*}{$\begin{array}{c}\text { Salinity } \\
\text { Treatments }\end{array}$} & \multicolumn{4}{|c|}{ Total Number of Rotifer $\left(10^{6} / 30 \mathrm{~L}\right)$} & \multirow{2}{*}{$\begin{array}{l}\text { Final Density } \\
\text { (Ind./ml)** }\end{array}$} & \multirow{2}{*}{$\begin{array}{c}\text { Total } \\
\text { Increment } \\
\left(\mathrm{X10}^{6} / 3\right. \\
\text { days/30L) }\end{array}$} & \multirow{2}{*}{$\begin{array}{c}\text { Average Daily } \\
\text { Increment } \\
\left(\mathrm{X} 10^{6} / 3 \text { days }\right. \\
\text { /30L })\end{array}$} & \multirow{2}{*}{$\begin{array}{c}\text { Average daily } \\
\text { Increment } \\
(\%)\end{array}$} \\
\hline & Day0* & Day 1 & Day 2 & Day 3 & & & & \\
\hline 25 & 1.50 & $2.365 \pm 0.495^{\mathrm{a}}$ & $3.285 \pm 0.021^{\mathrm{a}}$ & $3.365 \pm 0.007^{\mathrm{a}}$ & $112.2 \pm 0.212^{\mathrm{a}}$ & $1.865 \pm 0.007^{\mathrm{a}}$ & $0.621 \pm 0.002^{\mathrm{a}}$ & $41.33 \pm 0.00^{\mathrm{a}}$ \\
\hline 27 & 1.50 & $2.100 \pm 0.042^{\mathrm{bd}}$ & $\begin{array}{l}3.240 \pm 0 \\
042^{\mathrm{a}}\end{array}$ & $3.295 \pm 0.007^{\mathrm{a}}$ & $109.9 \pm 0.211^{\mathrm{a}}$ & $1.795 \pm 0.007^{\mathrm{a}}$ & $0.599 \pm 0.002^{\mathrm{a}}$ & $40.00 \pm 0.00^{\mathrm{a}}$ \\
\hline 29 & 1.50 & $2.000 \pm 0.014^{\mathrm{cd}}$ & $2.130 \pm 0.042^{\mathrm{b}}$ & $2.820 \pm 0.042^{\mathrm{b}}$ & $94.0 \pm 1.411^{\mathrm{b}}$ & $1.320 \pm 0.042^{\mathrm{b}}$ & $0.440 \pm 0.014^{b}$ & $29.34 \pm 0.94^{\mathrm{b}}$ \\
\hline Average & 1.50 & $2.155 \pm 0.171 * *$ & $2.885 \pm 0.586 * *$ & $3.160 \pm 0.266 * *$ & $105.33 \pm .860 * *$ & $1.66 \pm 0.266 * 8$ & $0.553 \pm 0.088^{* *}$ & $36.88 \pm 5.59 * *$ \\
\hline
\end{tabular}

* Initial density was $50 \mathrm{Ind} . / \mathrm{ml}$. **The volume of the rotifer tank is 30 liter of water culture. ***means in within same column sharing same superscript are not significantly different $(p \leq 0.05)$

Table 4: Effect of different water temperatures on the productive performance of rotifers $B$. plicatilis

\begin{tabular}{|c|c|c|c|c|c|c|c|c|}
\hline \multirow{2}{*}{$\begin{array}{l}\text { Temperature } \\
\text { Treatments }{ }^{\circ} \mathrm{C}\end{array}$} & \multicolumn{4}{|c|}{ Total Number of Rotifer $\left(10^{6} / 30 \mathrm{~L}\right)$} & \multirow{2}{*}{$\begin{array}{c}\text { Final Density } \\
\text { (Ind./ml)** }\end{array}$} & \multirow{2}{*}{$\begin{array}{c}\text { Total } \\
\text { Increment } \\
\left(\times 10^{6} / 3\right. \\
\text { days/30L })\end{array}$} & \multirow{2}{*}{$\begin{array}{c}\text { Average } \\
\text { Daily } \\
\text { Increment } \\
\text { (x10 } 6 \text { /3 days } \\
\text { /30L) }\end{array}$} & \multirow{2}{*}{$\begin{array}{c}\text { Average daily } \\
\text { Increment (\%) }\end{array}$} \\
\hline & Day0* & Day 1 & Day 2 & Day 3 & & & & \\
\hline 26 & 1.50 & $2.140 \pm 0.112^{\mathrm{bc}}$ & $3.265 \pm 0.062^{\mathrm{a}}$ & $3.600 \pm 0.085^{\mathrm{a}}$ & $120 \pm 2.828^{\mathrm{a}}$ & $2.10 \pm 0.085^{\mathrm{a}}$ & $0.70 \pm 0.028^{\mathrm{a}}$ & $46.7 \pm 1.888^{\mathrm{a}}$ \\
\hline 28 & 1.50 & $2.350 \pm 0.056^{\mathrm{a}}$ & $3.450 \pm 0.042^{\mathrm{cd}}$ & $3.900 \pm 0.276^{\mathrm{a}}$ & $130 \pm 9.192^{\mathrm{a}}$ & $2.40 \pm 0.276^{\mathrm{a}}$ & $0.80 \pm 0.092^{\mathrm{a}}$ & $53.3 \pm 6.131^{\mathrm{a}}$ \\
\hline 30 & 1.50 & $2.420 \pm 0.057^{\mathrm{a}}$ & $3.380 \pm 0.055^{\mathrm{ad}}$ & $3.750 \pm 0.212^{\mathrm{a}}$ & $125 \pm 7.071^{\mathrm{a}}$ & $2.25 \pm 0.212^{\mathrm{a}}$ & $0.75 \pm 0.071^{\mathrm{a}}$ & $50.0 \pm 4.709^{\mathrm{a}}$ \\
\hline 32 & 1.50 & $2.280 \pm 0.042^{\mathrm{ac}}$ & $2.640 \pm 0.085^{\mathrm{b}}$ & $3.000 \pm 0.178^{\mathrm{b}}$ & $100 \pm 5.656^{\mathrm{b}}$ & $1.50 \pm 0.184^{\mathrm{b}}$ & $0.50 \pm 0.057^{\mathrm{b}}$ & $33.3 \pm 3.769^{b}$ \\
\hline A & 1.50 & $2.298 \pm 0.12$ & $3.18 \pm 0.34 * *$ & $3.562 \pm 0.40 *$ & $119 \pm 13.53^{*}$ & $2.062 \pm 0.40 *$ & $0.687 \pm 0.13 *$ & $45.825 \pm 9.02 *$ \\
\hline
\end{tabular}

* Initial Density was $50 \mathrm{lnd} . / \mathrm{ml}$. ** The volume of the rotifer tank is 30 liter of water culture. ***means in within same column sharing same superscript are not significantly different $(p \leq 0.05)$ 


\section{Effect of water Temperature:}

The results of the effect of different water temperatures (26, 28, 30 and 32 $\left.{ }^{\circ} \mathrm{C}\right)$ on rotifers (B. Plicatilis) population showed that there were significant differences between all treatments $(P \leq 0.05)$, as showed in Table 4.

In the first day, the results showed that the highest significant total number of rotifer was achieved at temperature $32{ }^{\circ} \mathrm{C}\left(2.280 \pm 0.042 \times 10^{6} / 30 \mathrm{~L}\right)$ followed by $30 \stackrel{\circ}{\circ} \quad\left(2.420 \pm 0.057 \times 10^{6} / 30 \mathrm{~L}\right)$, and $28 \stackrel{\circ}{\circ} \mathrm{C}\left(2.350 \pm 0.056 \times 10^{6} / 30 \mathrm{~L}\right)$, while the lowest was achieved by $26^{\circ} \mathrm{C}\left(2.140 \pm 0.112 \times 10^{6} / 30 \mathrm{~L}\right)$. In the second day, our results showed that the highest significant total number of rotifer was achieved by temperature $30 \stackrel{\circ}{\circ}\left(3.380 \pm 0.055 \times 10^{6} / 30 \mathrm{~L}\right)$ followed by $28{ }^{\circ} \mathrm{C}$ $\left(3.450 \pm 0.042 \times 10^{6} / 30 \mathrm{~L}\right)$, and $26 \stackrel{\circ}{\mathrm{C}}\left(3.265 \pm 0.062 \times 10^{6} / 30 \mathrm{~L}\right)$, while the lowest was achieved by $32 \stackrel{\circ}{\circ}\left(2.640 \pm 0.085 \times 10^{6} / 30 \mathrm{~L}\right)$, as well as, the results obtained from the third day observed that the temperature $28^{\circ} \mathrm{C}$ achieved the highest significant total number of rotifer $\left(3.900 \pm 0.276 \times 10^{6} / 30 \mathrm{~L}\right)$, followed by $30{ }^{\circ} \mathrm{C}$ $\left(3.750 \pm 0.212 \times 10^{6} / 30 \mathrm{~L}\right)$, and $26^{\circ} \mathrm{C}\left(3.600 \pm 0.085 \times 10^{6} / 30 \mathrm{~L}\right)$, while the lowest was achieved by $32^{\circ} \mathrm{C}\left(3.000 \pm 0.178 \times 10^{6} / 30 \mathrm{~L}\right)$, as shown in Figure 3 . On the other hand, the highest significant final density $(\mathrm{Ind} . / \mathrm{ml})$ of $B$. plicatilis was achieved by temperature $28 \stackrel{\circ}{\circ}(130 \pm 9.192 \mathrm{Ind} . / \mathrm{ml})$, followed by $30{ }^{\circ} \mathrm{C}$ $(125 \pm 7.071 \mathrm{lnd} . / \mathrm{ml}), 26{ }^{\circ} \mathrm{C}(120 \pm 2.828 \mathrm{Ind} . / \mathrm{ml})$, while the lowest was achieved by $32{ }^{\circ} \mathrm{C}(100 \pm 5.656 \mathrm{Ind} . / \mathrm{ml})$ According the results, the highest significant daily increment percentage (\%) was achieved by $28{ }^{\circ} \mathrm{C}(53.3 \%), 30{ }^{\circ} \mathrm{C}(50 \%)$, and $26{ }^{\circ} \mathrm{C}(46.7 \%)$, while the lowest was achieved by $32^{\circ} \mathrm{C}(33.3 \%)$.

\section{Effect of Initial rotifer density:}

The results of the effect of different initial density of rotifer $(50,100,150$ and $200 \mathrm{Ind} . / \mathrm{ml}$ ) on rotifers (B. Plicatilis) population showed that there were significant differences between all treatments $(P \leq 0.05)$, as showed in Table 5 .

In the first day, the present result showed that the highest significant total number of rotifer was achieved by density $150\left(3.48 \pm 0.08 \times 10^{6} / 30 \mathrm{~L}\right)$ followed by $200\left(2.64 \pm 0.04 \times 10^{6} / 30 \mathrm{~L}\right)$, and then $100(2.25 \pm 0.04)$, while the lowest was achieved by density $5010^{6} / 30 \mathrm{~L}\left(1.11 \pm 0.17 \times 10^{6} / 30 \mathrm{~L}\right)$. In the second day, our results showed that the highest significant total number of rotifer was achieved by $200\left(4.58 \pm 0.01 \times 10^{6} / 30 \mathrm{~L}\right)$ followed by $150\left(4.50 \pm 0.13 \times 10^{6} / 30 \mathrm{~L}\right)$, and then $100\left(4.05 \pm 0.04 \times 10^{6} / 30 \mathrm{~L}\right)$, while the lowest population was achieved by density $5010^{6} / 30 \mathrm{~L}\left(2.23 \pm 0.18 \times 10^{6} / 30 \mathrm{~L}\right)$. As well as, the results obtained from the third day showed that the highest significant total number of rotifer was achieved by density $150\left(6.48 \pm 0.01 \times 10^{6} / 30 \mathrm{~L}\right)$ followed by $200\left(5.91 \pm 0.04 \times 10^{6} / 30 \mathrm{~L}\right)$, and then $100\left(4.80 \pm 0.00 \times 10^{6} / 30 \mathrm{~L}\right)$, while the lowest was achieved by density 50 Ind./ml . (3.12 $\left.\pm 0.00 \times 10^{6} / 30 \mathrm{~L}\right)$, as shown in Figure 4.

On the other hand, the highest significant final density (Ind./ml) of $B$. plicatilis was achieved by $150(216.0 \pm 0.42 \mathrm{Ind} . / \mathrm{ml})$, followed by $200(197.0 \pm 1.41$ Ind./ml), and $100(160.0 \pm 0.14 \mathrm{lnd} . / \mathrm{ml})$, while the lowest was achieved by 50 Ind./ml (104 \pm 0.14 Ind./ml). Moreover, the highest significant daily increment percentage (\%) was achieved by 50 (105.20\%), 100 (73.20\%), and 150 (62.80 $\%)$, while the lowest was achieved by 200 (32.3\%). 
Table 5: Effect of different initial rotifer density on the productive performance of Rotifers (B. Plicatilis) during the second phase study

\begin{tabular}{|c|c|c|c|c|c|c|c|c|}
\hline \multirow{2}{*}{$\begin{array}{l}\text { Initial density } \\
\text { Treatments }\end{array}$} & \multicolumn{4}{|c|}{ Total Number of Rotifer $\left(10^{6} / 30 \mathrm{~L}\right)$} & \multirow{2}{*}{$\begin{array}{c}\text { Final Density } \\
\text { (Ind./ml)*** }\end{array}$} & \multirow{2}{*}{$\begin{array}{c}\text { Total } \\
\text { Increment } \\
\left(\mathbf{x 1 0}^{6} / 3\right. \\
\text { days/30L })\end{array}$} & \multirow{2}{*}{$\begin{array}{c}\text { Average Daily } \\
\text { Increment } \\
\left(\mathbf{x 1 0}^{6} / 3 \text { days }\right. \\
\text { /30L })\end{array}$} & \multirow{2}{*}{$\begin{array}{l}\text { Average daily } \\
\text { Increment (\%) }\end{array}$} \\
\hline & Day 0 & Day 1 & Day 2 & Day 3 & & & & \\
\hline 50 & 0.75 & $1.11 \pm 0.17^{\mathrm{a}}$ & $2.23 \pm 0.18^{\mathrm{a}}$ & $3.12 \pm 0.00^{\mathrm{a}}$ & $104.0 \pm 0.14^{\mathrm{a}}$ & $2.37 \pm 0.00^{\mathrm{a}}$ & $0.79 \pm 0.00^{\mathrm{a}}$ & $105.20 \pm 0.21^{\mathrm{a}}$ \\
\hline 100 & 1.50 & $2.25 \pm 0.04^{\mathrm{b}}$ & $4.05 \pm 0.04^{\mathrm{b}}$ & $4.80 \pm 0.00^{\mathrm{b}}$ & $160.0 \pm 0.14^{\mathrm{b}}$ & $3.30 \pm 0.01^{\mathrm{b}}$ & $1.10 \pm 0.00^{\mathrm{b}}$ & $73.20 \pm 0.21^{\mathrm{b}}$ \\
\hline 150 & 2.25 & $3.48 \pm 0.08^{\mathrm{c}}$ & $4.50 \pm 0.13^{\mathrm{c}}$ & $6.48 \pm 0.01^{\mathrm{c}}$ & $216.0 \pm 0.42^{\mathrm{c}}$ & $4.23 \pm 0.01^{\mathrm{c}}$ & $1.42 \pm 0.01^{\mathrm{c}}$ & $62.80 \pm 0.07^{\mathrm{c}}$ \\
\hline 200 & 3.00 & $2.64 \pm 0.04^{\mathrm{d}}$ & $4.58 \pm 0.01^{\mathrm{c}}$ & $5.91 \pm 0.04^{\mathrm{d}}$ & $197.0 \pm 1.41^{\mathrm{d}}$ & $2.91 \pm 0.04^{\mathrm{d}}$ & $0.97 \pm 0.01^{\mathrm{d}}$ & $32.34 \pm 0.47^{\mathrm{d}}$ \\
\hline Average & 1.87 & $2.37 \pm 0.91 * *$ & $3.84 \pm 1.02 * *$ & $5.08 \pm 1.37 * *$ & $169.3 \pm 45.67 * *$ & $3.20 \pm 0.73 * *$ & $1.07 \pm 0.24 * *$ & $68.35 \pm 27.80^{* *}$ \\
\hline
\end{tabular}

The volume of the rotifer tank is 30 liter of water culture. .***means in within same column sharing same superscript are not significantly different $(p \leq 0.05)$

\section{DISCUSSION:}

The microalga (Nannochloropsis) is widely used in the laboratory and in commercial hatcheries for culturing $B$. plicatilis because it supports higher rotifer survival and reproduction rates and contains adequate highley unsaturated fatty acid (HUFA) especially, EPA (Kobayashi et al., 2008). Our results found that rotifer fed on live $N$. oculata achieved final population, as well as EPA and DHA, higher than rotifer fed on dried $S$. platensis. These results indicated that $N$. oculata may be the best microalgal species used as rotifer feed (Ashour, 2011). On the other hand, Nhu (2004) studied the effects of different four feeding types: (1) bakers' yeast (Saccharomyces cerevisiae) in wet form plus 10\% squid liver oil (by dry weight), (2) S. cerevisiae in dry form plus 10\% squid liver oil, (3) microalgae (Nannochloropsis oculata) and (4) microalgae (Chaetoceros muelleri) on growth and quality of rotifer of the L-strain. The results showed that there were significant differences in rotifer growth rate, viability, size and ciliate contamination between the four dietary treatments $(P<0.05)$. Moreover, rotifers fed on microalgae showed better viability, larger size and low ciliate contamination compared to those fed on yeast. These findings were supported the results of the present study. the highest final rotifer population and the highest content of EPA and DHA were achieved by rotifer fed on $N$. oculata supplemented by beaker yeast (NY). However, the combination between $N$. oculata and beaker yeast have some advantages; (1) reduced the rotifer production cost, (2) enhanced rotifer quantity (population) and quality (EPA and DHA percentage), and (3) reduced the contamination occurred while using beaker yeast only.

Evaluating rotifer growth parameters to maximize productivity is important under different management condition (Fotoon et al., 2007). Both temperature and salinity will directly influence the reproductive rate of the rotifer, and the response in general depends on strain and environmental conditions (Miracle and Serra, 1989). Salinity had also a greater effect on rotifer than temperature (Fielder et al., 2000).

The rotifer $B$. plicatilis tolerates salinities ranging from 1 to 97 ppt (Walker, 1981). Viayeh, et al., (2010) found that the maximum final population density of rotifer (B. urceolaris) strain fed on Nannochloropsis was at 20 ppt(brackish 
water), while final population density of rotifer (B. plicatilis) strain fed on Chlorella was at 10 and 30 ppt.During the present study(brackish water) the salinity 25 ppt possessed the highest final number of rotifer, comparing to salinity 27 and 29 ppt (with using NY as rotifer feed). The differences in these results may be due to the difference of rotifer food and/or rotifer and algal strains. However, the present study illustrated that the decrease of salinity degree (from 29 to $25 \mathrm{ppt}$ ) caused increasing of the final number of rotifer ( $B$. Plicatilis).

Fielder et al. (2000) investigate the effect of rapid changes in temperature and salinity on availability of the rotifers (Brachionus rotundiformis) and (Brachionus plicatilis) and they concluded that rotifers should be cultured at lower temperatures and similar salinities to the fish larval rearing tanks or acclimated for at least $6 \mathrm{~h}$ to larval rearing conditions. The results of the present study reported that the temperature $28 \stackrel{\circ}{C}$ recorded the highest significant final number of rotifer in addition $28 \stackrel{\circ}{\circ}$ recorded also the highest final density $(130 \pm$ $9.192 \mathrm{lnd} . / \mathrm{ml}$ ) and average daily Increment percentage (53.3\%), comparing to 26, 30, and $32{ }^{\circ} \mathrm{C}$ (under NY and 25 ppt treatments conditions).

In conclusion, the present study illustrated salinity $25 \mathrm{ppt}$, temperature 28 ${ }^{\circ} \mathrm{C}$ and initial rotifer density of $150 \mathrm{Ind} / \mathrm{ml}$ recorded the highest rotifer quality, growth and production under $50 \%$ N.oculata $+50 \%$ beaker yeast (NY) feeding conditions.

\section{REFERENCES}

Ashour, M. F. 2011. Studies on culture of some marine microalgae and its utilization as feed for some invertebrates and fish larvae. M.Sc. Thesis, Library of National Institute of Oceanography and Fisheries (NIOF), Alexandria branch, Egypt.

Fulks, W. and Main, K.L., 1991.Rotifer_Brachionus plicatilis.production systems. In: Fulks, W., Main, K.L. Eds.., Rotifer and Microalgae Culture Systems. Proceedings of a US-Asia Workshop, Honolulu, HA, January 28-31. pp. 3-52.

Fielder, D. S., Purser G.J., and Battaglene S.C. 2000.Effect of rapid changes in temperature and salinity on availability of the rotifers Brachionus rotundiformis and Brachionus plicatilis. Aquaculture, 189:85-99.

Ferreira, M., Pedro Seixas, Paula Coutinho, Jaime Fábregas and Ana Otero. 2011. Effect of the Nutritional Status of Semi-continuous Microalgal Cultures on the Productivity and Biochemical Composition of Brachionus plicatilis. Mar Biotechnol 13:1074-1085.

Fotoon A.Q. Sayegh, Naseem Radi, and David J.S. Montagnes. 2007. Do strain differences in microalgae alter their relative quality as a food for the rotifer Brachionus plicatilis?. Aquaculture, Volume 273, Issue 4, 20 December 2007, Pages 665-678.

Kobayashi, T., Nagase, T., Hino, A. And Takeuchi, T., 2008. Effect of combination of feeding Nannochloropsis and freshwater Chlorella on the fatty acid composition of rotifer Brachionus plicatilis in a continuous culture. Fisheries Science, 74: 649-656.

Lubzens, E., Minkoff, G., Barr, Y. Zmora, O. 1997. Mariculture in Israel-past achievements and future directions in raising rotifers as food for marine fish larvae. Hydrobiologia, 358: 13-20. 
Lubzens, E., Zmora, O. and Barr, Y. 2001. Biotechnology and aquaculture of rotifers. Hydrobiologia, 186 (187): 387-400.

Miracle, M.R. Serra, M. 1989. Salinity and temperature influence in rotifer life history characteristics. Hydrobiologia, 52: 81-102.

Nhu, C.V. 2004. A Comparison of Yield and Quality of the Rotifer (Brachionus plicatilis - L-strain) Fed Different Diets Under Aquaculture Conditions, Vietnam. Asian Fisheries Science, 17: 357-363.

Qie, G., Reitan, K.I., Evjemo, J.O., Stqttrup, J., and Olsen, Y. 2011. Live feeds, In: Holt, G.J. (Ed.), Larval Fish Nutrition, first ed. John Wiley \& Sons, Inc., pp. 307-334.

Radwan, S. S. 1978. Coupling of two dimensional thin layer chromatography for the quantitive analysis of lipid classes and their constituent fatty acids. J. Chromatogr. Sci., 16: 538-542.

Steel R.G.D. and Torrie, J.H. (1980), Principles and Procedures of Statistics, SecondEdition, New York: McGraw-Hill Book Co.

Viayeh R.M, H. Mohammadi and A. B. Shafiei. 2010. Population Growth of Six Iranian Brachionus Rotifer Strains In Response To Salinity And Food Type. International Review of Hydrobiology, Volume 95, Issue 6, pages 461-470.

Walker, K.F., 1981. A synopsis of ecological information on the saline lake rotifer Brachionus plicatilisMu"ller 1786.Hydrobiologia, 81: 159-167.

Wendy Fulks and Kevan Main. 1991. Rotifer and Microalgae culture systems. Honolulu, Hawaii, January 28-31.

Yin, X.W. and Zhao, W., 2008.Studies on life history characteristics of Brachionus plicatilis O. F. Müller (Rotifera) in relation to temperature, salinity and food algae.Aquatic. Ecology, 42: 165-176. 


\section{الملخص العربى}

\section{العوامل الحيويه وغير الحيويه وتأثيرها على إنتاج وكثافه نمو الروتيفير بنظام الاستزراع بالدفعات (3 ايام )}
إجلال على عمر ${ }^{2}$ 1- قسم الانتاج الحيوانى والسمكى - كليه الزراعه سابا باشنا - جامعه الاسكندريه 2 - المعهد القومى لعلوم البحار والمصايد - ألانفوشى - الاسكندريه

تعتبر الحوامات الدوارة (الروتيفرا) لها دور هام فى تغذية يرقات الاسماك البحرية والقشريات. كما انها مهمه لامداد يرقات الاسماك البحرية بالمغذيات والفيتامينات والاحماض الدهنية والاجسام المضادة، حيث ان نوع التغذية هام وله تاثير على نمو ونوعية الحوامات الدوارة (الروتيفرا). ويهدف هذا البحث الى دراسة تاثير نوع التغذية والملوحة ودرجة الحرارة وكثافة التلقيح على نمو وكثافة الروتيفير • المرحله الاولى : تم فيها ملاحظة تاثير اربع معاملات مختلفة من الطحالب البه

$$
\begin{aligned}
& \text { 1- نانو كلوربسس اكيولاتا ( حية) . } \\
& 2 \text { - سبيرولينا بلانتس (مسحوق) • } \\
& \text { 3- خليط من النانو والخميرة . }
\end{aligned}
$$

4- خليط من الاسبيرولينا والخميرة على انتاج الروتيفرا .

وتم تعين نسبة الاحماض الدهنية فى الروتيفرا وكان نظام الاستزراع بنظام الدفعات لمدة 72 ساعة فى احواض ترون فيير جلاس سعة الحوض 30 لتر بثلاث مكرارات لكل معاملة ـ واظهرت النتائج ان المعاملة رقم 3 وهى خليط من لانس النانوكلوروبسيس والخميرة الجافة هى الافضل فى التغذية فى هذه التجربة . المرحله الثانيه : وتم دراسة العوامل البيئية وهى الملوحة بمعاملات 25 - 27 - 29 جزء فى الالف ودرجة حرارة

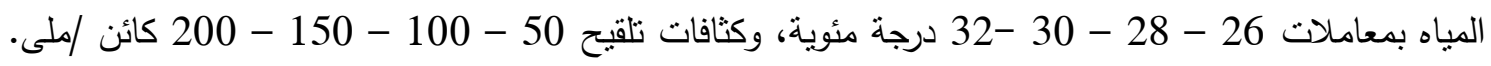
وقد اظهرت النتائج أن افضل المعاملات البيئية 25 جزء فى الالف للملوحه و 28 درجة مئوية للحراره وكثافة تلقيح 150 كائن /ملى. 
